\title{
Elementary School Third Grade Students' Expectations of Their Teachers in The Course of Language Education
}

\author{
Sabri Sidekli ${ }^{1}$, Zeliha Cura ${ }^{2}$, Alper Yorulmaz ${ }^{3}$ \\ ${ }^{1,3}$ Department of Elementary Education, Faculty of Education, Mugla Sitk1 Kocman University, Turkey \\ ${ }^{2}$ Primary School Teacher, Ministry of Education, Turkey
}

\begin{tabular}{l} 
Article Info \\
\hline Article history: \\
Received May 26, 2018 \\
Revised May 27, 2018 \\
Accepted May 30, 2018 \\
\hline
\end{tabular}

Keyword:

Elementary school

Expectation

Language education

Student

Teacher

\begin{abstract}
The purpose of the study is to determine the elementary school third grade students' expectations of their classroom teachers within the context of the course of language education. The sampling of the study is comprised of 200 elementary school third grade students attending elementary schools in the Milas Province of the city of Muğla. The data were gathered by means of the questionnaire, which had six sub-categories, in order to identify students' expectations of their teachers. The findings of the study revealed that the students have high expectations of their teachers in terms of the subdimensions of active participation, verbal participation, written participation, participating in reading, inclusion of the topics and measurement and evaluation. The students' expectations of their teachers in relation to the subdimension of measurement and evaluation were found to be varying significantly depending on the gender variable. This difference is in favor of boys.
\end{abstract}

Copyright $(\mathrm{C} 2018$ Institute of Advanced Engineering and Science. All rights reserved.

\section{Corresponding Author:}

Alper Yorulmaz

Department of Elementary Education,

Mugla Sitkı Kocman University,

Kotekli, Mugla County 48000, Turkey.

Email: alperyorulmaz@mu.edu.tr

\section{INTRODUCTION}

From birth to death, human beings have to adapt to the social environment in which they live. This adaptation is only possible through learning. Education started with the existence of learning and still continues. The main objective of education is to create individuals who can keep up with the age, think, are open to change and innovation, question, criticize, can express their opinions freely and learn to learn by using the ways of having access to information. Accomplishment of the objectives of education is possible through the effective arrangement of instructional activities according to students' needs and interests. The person who organizes the instructional activities and implements the instructional process effectively is the teacher. An effective teacher is not the one who transmits knowledge to students rather the one who can find and implement methods that can facilitate learning for students with individual differences [1].

It is not enough just to improve the physical environment and tools and equipments to increase efficiency in education. Besides tools and equipments used in education, the human factor particularly represented by the teacher figure is of great importance. The quality and proficiency of the teacher are directly related to the quality of education [2] and an important factor determining the success of educationalinstructional activities [3]. The teacher needs to adopt a role of someone who facilitates the acquisition of the necessary information and prepares the suitable environments. In order to fulfill the requirements of this role, the teacher must be interested and willing at least as much as his/her students [4]. Moreover, the teacher should make his/her students active and develop sensitive characteristics [5]. 
In the development of students, language plays an important role. Through the effective use of language, they can communicate well, acquire information, and develop themselves. Language makes important contributions to them by enabling them to make decisions through questioning, to evaluate events from different perspectives, to socialize and to modernize [6]. Therefore, students need to be well equipped with the basic skills of language. The objective of language education in the training of individuals of today and future is not only the inculcation of technical skills such as listening, speaking, reading and writing but also to foster students' cognitive skills such as thinking across texts, comprehension, sequencing, classification, questioning, establishing connections, criticizing, analysis-synthesis and evaluation and skills of using the brain technology [6]. That is, language education is a very important factor in the creation of individuals who criticize, question, establish communication, have problem solving skills, can keep with the society, are responsible for their own learning and entrepreneurs. Thus, language education should aim to impart these skills to students.

For students to be equipped with these skills through language education, the teacher should fulfill some duties and responsibilities because the teacher creates long-lasting effects on students with their attitudes and behaviors; thus, affects their cognitive and affective characteristics. There is a direct connection between students' academic achievement, social development and communication skills and the teacher's behaviors. Thus, due to their direct effect on academic achievement, their effect on their students can be forever [7].

Expectation refers to a state of making inferences about what might happen in the future on the basis of previous experiences. The teacher expectation on the other hand refers to his/her inferences about his/her students' present and future academic achievement and classroom behaviors on the basis of what he/she knows about them [8]. In other words, the teacher's conviction and attitude in relation to how much a student can learn and how a student can perform are called teacher expectation [9, 10, 11, 12]. Teachers' expectations are influenced by students' attitudes, behaviors and their approaches. $[13,14,15]$.

Though teachers may not be aware of the fact their behaviors are affected by their expectations of students, students are always cognizant of this because teachers cannot hide their actual feelings [16]. They show their feelings through the tone of voice, posture, facial expressions and eye contact and at the same time in this way, they indicate their expectations of their students. Teachers' behaviors can be told to be shaped in line with their expectations of their students. The teacher's expectations of a student are related to the student's academic expectations of the teacher. When the teacher is indifferent and exhibit negative attitudes, then the student becomes indifferent to lessons. Therefore, each student wants their teachers to love them, to be affectionate to them, to trust them, to value them, to be patient, not to level destructive criticism, to be sensitive against problems, to be tolerant, to deliver the lesson enthusiastically and willingly and to be qualified in their subject areas [17]. When the teacher cannot meet such expectations, it can be difficult for students to love the course of language education, to invest enough effort and to achieve a certain level of learning [6]. This shows that there is a strong correlation between student expectations and teacher behaviors [18].

For students to develop positive attitudes towards the course of language education first their expectations of their teachers should be determined and teachers should conduct their activities in accordance with these expectations. In the literature the number of studies addressing the issue of students' expectations of their teachers seems to be quite low. This small number of studies is also directed to secondary and higher education students and there are very few studies focusing on elementary school students in the literature. Therefore, in the current study, it is aimed to determine the elementary school third grade students' expectations of their classroom teachers in relation to the course of language education and to present its results to teachers and researchers. To this end, the problem statement of the study was set to be as follows "What are the elementary school third grade students' expectations of their classroom teachers in the course of language education?"

\section{RESEARCH METHOD}

The current study employed the survey method; one of the qualitative research method, to determine an existing state. As the survey method is generally used to elicit the attitudes, beliefs and opinions of a selected group about a specific issue in educational research [19], it was selected as the research design of the current study.

\subsection{Universe and Sampling}

The universe of the study is comprised of the elementary school third grade students enrolled at the schools in the Milas Province of the city of Muğla in 2015-2016 school year. The sampling consists of 200 elementary school third grade students. Of these students, 125 are girls and 75 are boys.

IJERE Vol. 7, No. 2, June 2018: 159-166 


\subsection{Data Collection Tools}

In order to determine the elementary school third grade students' expectations of their classroom teachers teaching the course of language education, a data collection tool developed by Sidekli (2010) and consisting of 33 items and 6 sub-dimensions was used. In addition to this data collection tool, a personal information form was also used to elicit the personal information of the participating students. The reliability coefficients calculated for each sub-dimension of the questionnaire developed by Sidekli (2010) are as follows; active participation in the course of language education (.61), verbal participation in the course of language education (.65), participation in writing activities in the course of language education (.76), participating in reading activities in the course of language education (.72), orientation to the subjects of the course of language education (.80) and measurement and evaluation in the course of language education (.78). The general Cronbach alpha value of the measurement tool was found to be .81 . The Cronbach alpha coefficient of the measurement tool in the current study was found to be .79 . The scale items are designed as 3-point Likert scale with response options ranging from "I always want", "I sometimes want" to "I never want".

\subsection{Data Analysis}

In the analysis of the data collected from 200 elementary school third grade students, IBM SPSS 21 statistical program package was used. In the data analysis process, first the frequencies and percentages were calculated for the items. In order to decide whether parametric or non-parametric tests would be used in order to test whether the sub-dimensions vary depending on the gender variable, Kolmogorov-Smimov test ( $>$.05) was run to test the normality of the distribution of the data. As it was determined that the data exhibited a normal distribution, t-test was used in the difference analysis. The questionnaire items designed in the form of a three-point Likert scale were scored by assigning scores ranging from 1 to 3 .

\section{RESULTS AND DISCUSSION}

In line with the general purpose of the study, the analysis results related to the sub-problems are presented in tables and then interpreted.

Elementary school third grade students' expectations of their teachers in terms of active participation in language classes are shown in Table 1.

Table 1. Frequencies and Percentages of the Responses Given to the Items in the Sub-Dimension of Active Participation in Activities in the Course of Language Education

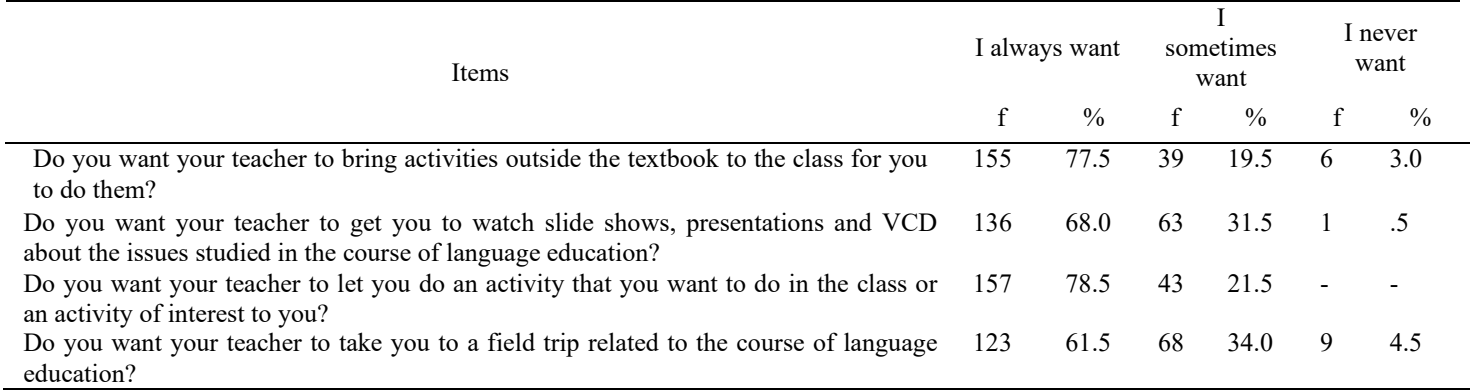

As can be seen in Table 1, the students' expectations of their teachers are high in related to the skill of actively participating in activities. Of the students, $61,5 \%$ expect from their teachers to take them to field trips and $68 \%$ expect their teachers to make them watch slide shows, VCDs and presentations. The ratio of the students expecting their teachers to bring activities different from the ones given in their textbooks to do in the class was found to be $77.5 \%$. The highest expectation of teachers within the sub-dimension of active participation is their conducting activities in the course of language education complying with the interests of students.

These findings indicate that the students are willing to interact with their students in language education classes. As the students are willing to participate actively in lessons, it can be assumed that conducting student-centered activities in the classroom might be necessary. Doing student-centered activities will positively affect students' academic achievement [20]. This finding may lead us to the conclusion that delivering the lesson by using the activities selected by students and thus in which they are willing to 
participate will increase their academic achievement. Similarly, in the study by Sidekli (2010), it was reported that students' active participation in lessons at their own discretion will foster their self-confidence.

Elementary school third grade students' expectations of their teachers in terms of verbal participation in language classes are shown in Table 2.

Table 2. Frequencies and Percentages of the Students' Responses Given to the Items Concerning the Verbal Participation in the Course of Language Education

\begin{tabular}{|c|c|c|c|c|c|c|}
\hline \multirow[t]{2}{*}{ Items } & \multicolumn{2}{|c|}{ I always want } & \multicolumn{2}{|c|}{$\begin{array}{l}\text { I } \\
\text { sometimes } \\
\text { want }\end{array}$} & \multicolumn{2}{|c|}{$\begin{array}{l}\text { I never } \\
\text { want }\end{array}$} \\
\hline & $\mathrm{f}$ & $\%$ & $\mathrm{f}$ & $\%$ & $\mathrm{f}$ & $\%$ \\
\hline $\begin{array}{l}\text { Do you want your teacher to let you freely express your opinions about the } \\
\text { subjects studied in the lesson? }\end{array}$ & 109 & 54.5 & 71 & 35.5 & 20 & 10.0 \\
\hline $\begin{array}{l}\text { Do you want your teacher to have you tell about a film you have watched on TV, } \\
\text { or stories or folk tales you have listened in the class? }\end{array}$ & 157 & 78.5 & 26 & 13.0 & 17 & 8.5 \\
\hline $\begin{array}{l}\text { Do you want your teacher to have you talk without making any preparation about } \\
\text { any subject at the beginning of the lesson for 5-10 minutes? }\end{array}$ & 146 & 73.0 & 35 & 17.5 & 19 & 9.5 \\
\hline $\begin{array}{l}\text { Do you want your teacher to provide you with an opportunity to tell what you } \\
\text { have read in a book, newspaper or magazine aside from your textbook to your } \\
\text { friends in the class? }\end{array}$ & 163 & 81.5 & 15 & 7.5 & 22 & 11.0 \\
\hline $\begin{array}{l}\text { Do you want your teacher to conduct play-like activities on the basis of speaking } \\
\text { activities such as whole-class discussion, group discussion or individual } \\
\text { communication? }\end{array}$ & 176 & 88.0 & 12 & 6.0 & 12 & 6.0 \\
\hline $\begin{array}{l}\text { Do you want your teacher to conduct speaking activities related to poems, stories } \\
\text { and folktales for your vocabulary to improve? }\end{array}$ & 170 & 85.0 & 19 & 9.5 & 11 & 5.5 \\
\hline
\end{tabular}

As in the sub-dimension of students' active participation, the students' expectations of the teacher in the sub-dimension of verbal participation are high. Of the students, $54.5 \%$ expect to express their opinions freely in the class and $73 \%$ expect to conduct free speaking activity without making any preparations about any subject for 5-10 minutes at the beginning of the lesson. Of the students, $78.5 \%$ expect to tell stories or folktales they have watched on $\mathrm{TV}$ or listened in the class and $81.5 \%$ expect to be provided with opportunities to tell what they have read in a book, newspaper or magazine aside from their textbook to their friends in the class. Of the students, $85 \%$ want to conduct speaking activities related to poems, stories and folktales to improve their vocabulary and $88 \%$ want their teachers to conduct play-like activities on the basis of speaking activities such as whole-class discussion, group discussion and individual communication.

In light of the findings of the current study, it can be suggested that play-like activities should be conducted and stories, poems and folktales should be presented in the classroom environment. As children at this age group like learning by playing, play-like activities should be incorporated into the routines of the course of language education, which seems to be important for the success of children. In the study by Tangülü, Çetin and Çava (2015) investigating students' expectations in the social studies course, it was found that the students want play-like speaking activities to a great extent. Moreover, it can be suggested that more importance should be attached to folktales, stories and poems in the class for the development of students' vocabulary repertoire. It can be thought that teachers' encouraging communication and interaction in the class, conducting play-like activities and using literary works such as poems, stories and folktales will increase students' achievement.

Elementary school third grade students' expectations of their teachers in terms of written participation in language classes are shown in Table 3 . As can be seen in Table 3, 51\% of the students sometimes want their teacher to have them write summaries about the subjects they have studied in the course of language education. Of the students, $46.5 \%$ expect their teacher to have them write compositions to be displayed in activity corners of the school and $49 \%$ expect their teacher to have them write about the subjects studied in the course of language education and related to the daily life. In the course of language education, $50.5 \%$ of the students want their teacher to have them continuously write, $53 \%$ want their teacher to have them write poems, $65 \%$ want their teacher to have them write stories and compositions and $80 \%$ want their teacher to have them do writing activities on the basis of pictures and texts in newspapers and journals.

These findings indicate that the students want to do writing activities related to daily life topics. Thus, it can be said that the students want to make their writing more meaningful by selecting their writing topics from daily life. In addition, as the students want to write stories and compositions, they need to be directed to the topics that will allow them to explain experiences and information suitable for their age. This seems to be necessary to develop students' creativity.

IJERE Vol. 7, No. 2, June 2018: 159-166 
Table 3. Frequencies and Percentages for the Students' Responses Given to the Items Involved in the SubDimension of Written Participation in the Course of Language Education

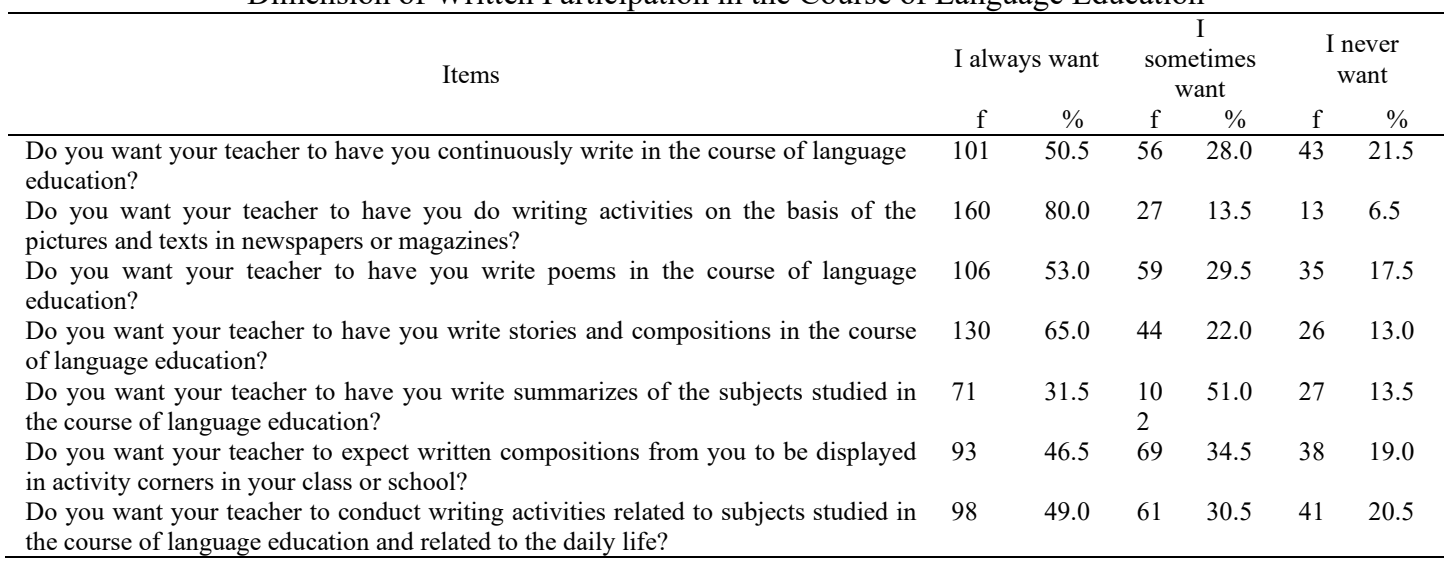

Elementary school third grade students' expectations of their teachers in terms of reading participation in language classes are shown in Table 4.

Table 4. Frequencies and Percentages for the Students' Responses Given to the Items Involved in the SubDimension of Reading Participation

\begin{tabular}{|c|c|c|c|c|c|c|}
\hline Items & \multicolumn{2}{|c|}{ I always want } & \multicolumn{2}{|c|}{$\begin{array}{l}\text { I sometimes } \\
\text { want }\end{array}$} & \multicolumn{2}{|c|}{$\begin{array}{c}\text { I never } \\
\text { want }\end{array}$} \\
\hline $\begin{array}{l}\text { Do you want your teacher to let you read the texts from journals, books or } \\
\text { newspapers related to the subjects of the course of language education in the } \\
\text { class? }\end{array}$ & 95 & 47.5 & 65 & 32.5 & 40 & 20.0 \\
\hline $\begin{array}{l}\text { Do you want your teacher to read texts from journals or newspapers which you } \\
\text { may like in the class? }\end{array}$ & 127 & 63.5 & 50 & 25.0 & 23 & 11.5 \\
\hline $\begin{array}{l}\text { Do you want your teacher to allocate one class hour from the class hours of the } \\
\text { course of language education for free reading? }\end{array}$ & 122 & 61.0 & 67 & 33.5 & 11 & 5.5 \\
\hline $\begin{array}{l}\text { Do you want your teacher to bring the newly published books about language } \\
\text { education suitable for your level to the class to increase your interest in reading? }\end{array}$ & 118 & 59.0 & 52 & 26.0 & 30 & 15.0 \\
\hline $\begin{array}{l}\text { Do you want your teacher to have you read more informative texts in the course of } \\
\text { language education? }\end{array}$ & 98 & 49.0 & 69 & 34.5 & 33 & 16.5 \\
\hline
\end{tabular}

As can be seen in Table 4, 47.5\% of the students want interesting texts from books, magazines and newspapers to be read in the class, $49 \%$ want more informative texts to be read, $51.5 \%$ want more informative texts to be read. Of the students, 59\% want newly published books suitable for their level to be brought to the class and introduced to them; $60 \%$ want to have a library in the class having course-related books suitable for their level; $61 \%$ want one class hour to be allocated for free reading and $63.5 \%$ want interesting texts from newspapers and magazines to be read in the class.

The students want interesting texts from newspapers and journals to be read in the class. This might indicate their willingness to be a part of the process through books, magazines and newspapers. Their expectation for the allocation of a free reading hour may indicate their desire to read independently and without guidance. In light of these findings, it can be said that the students' have high expectations for reading. This finding concurs with the findings reported by Sidekli (2010) as a result of his study to determine the $4^{\text {th }}$ and $5^{\text {th }}$ grade students' expectations.

Elementary school third grade students' expectations of their teachers in terms of inclusion of the subjects of language classes are shown in Table 5. 
Table 5. Frequencies and Percentages for the Students' Responses Given to the Items Involved in the Subdimension of the Inclusion of the Subjects in the Course of Language Education

\begin{tabular}{|c|c|c|c|c|c|c|}
\hline \multirow[t]{2}{*}{ Items } & \multicolumn{2}{|c|}{ I always want } & \multicolumn{2}{|c|}{$\begin{array}{l}\text { I } \\
\text { sometimes } \\
\text { want }\end{array}$} & \multicolumn{2}{|c|}{$\begin{array}{l}\text { I never } \\
\text { want }\end{array}$} \\
\hline & $\mathrm{f}$ & $\%$ & $\mathrm{f}$ & $\%$ & $\mathrm{f}$ & $\%$ \\
\hline $\begin{array}{l}\text { Do you want your teacher to first give concrete examples and then to teach the } \\
\text { subject while delivering language education lessons? }\end{array}$ & 123 & 61.5 & 61 & 30.5 & 16 & 8.0 \\
\hline $\begin{array}{l}\text { Do you want your teacher to inform you about where, when and how you can use the } \\
\text { subjects in the real life before starting to teach these subjects in the course of } \\
\text { language education? }\end{array}$ & 117 & 58.5 & 64 & 32.0 & 19 & 9.5 \\
\hline
\end{tabular}

As can be seen in Table 5, 48\% students want to be given homework to revise the subjects they have studied in the class; $57.5 \%$ want the allocation of more time for language education subjects; $58,5 \%$ want to be informed about where, when and how to use the subjects to be taught in the class and $61.5 \%$ want to be given concrete examples before the presentation of the subject.

The students stated that presentation of concrete examples before the instruction of any subject in the course of language education is important. Presentation of concrete examples can be important for meaningful learning to occur. Moreover, presentation of concrete examples is also supported by the principles of instruction; that is, presentation from concrete towards abstract. The students also want to know how the subject studied in the class relates to the real life. The reason for this might be because the students think that they feel more motivated when they know the information learned will be useful in the real life.

Elementary school third grade students' expectations of their teachers in terms of inclusion of assessment and evaluation in language classes are shown in Table 6.

Table 6. Frequencies and percentages for the students' responses given to the items involved in the subdimension of measurement and evaluation

\begin{tabular}{|c|c|c|c|c|c|c|}
\hline \multirow[t]{2}{*}{ Items } & \multicolumn{2}{|c|}{ I always want } & \multicolumn{2}{|c|}{$\begin{array}{l}\text { I } \\
\text { sometimes } \\
\text { want }\end{array}$} & \multicolumn{2}{|c|}{$\begin{array}{l}\text { I never } \\
\text { want }\end{array}$} \\
\hline & $\mathrm{f}$ & $\%$ & $\mathrm{f}$ & $\%$ & $\mathrm{f}$ & $\%$ \\
\hline Do you want your teacher to give exams in the course of language education? & 105 & 52.5 & 57 & 28.5 & 38 & 19.0 \\
\hline $\begin{array}{l}\text { Do you want your teacher to conduct assessment following each project work or } \\
\text { group activity? }\end{array}$ & 100 & 50.0 & 61 & 30.5 & 39 & 19.5 \\
\hline $\begin{array}{l}\text { Do you want your teacher to evaluate your comprehension of a story you have read } \\
\text { in the course of language education by asking questions? }\end{array}$ & 91 & 45.5 & 65 & 32.5 & 44 & 22.0 \\
\hline $\begin{array}{l}\text { Do you want your teacher to evaluate your comprehension of a story you have read } \\
\text { in the course of language education by making you draw pictures or perform similar } \\
\text { activities? }\end{array}$ & 100 & 50.0 & 58 & 29.0 & 42 & 21.0 \\
\hline
\end{tabular}

As can be seen in Table $6,45.5 \%$ of the students want their teacher to evaluate their comprehension of a story they have read by asking questions; $50 \%$ want the evaluation to be conducted after each project or group work. Of the students, $50 \%$ want their comprehension of a story they have read by means of drawings or similar activities; $52.5 \%$ want to be evaluated through exams and $65 \%$ expect their teacher to summarize what they have studied at the end of the lesson.

The students expect their teacher to continuously measure and evaluate their information and skills to be acquired in the course of language education. The students stated that at the end of the lesson, subjects studied should be summarized. This might be because the students have greater need for clear information and can acquire the information more easily in the summary. Moreover, the students expect to be examined in the course of language education. This might indicate that the classical understanding of education is still dominant among the students. In addition to this, most of the students also want their teacher to test their comprehension of a story read in the class by having them draw pictures or do similar activities. This shows that the students expect to undergo in-class evaluation.

Elementary school third grade students' expectations of their teachers in terms of gender in language classes are shown in Table 7.

IJERE Vol. 7, No. 2, June 2018: 159-166 
Table 7. T-test results showing the relationship between the students' expectations of their classroom teachers and their gender

\begin{tabular}{|c|c|c|c|c|c|c|c|}
\hline & Gender & $\mathrm{N}$ & $\mathrm{X}$ & Ss & df & $\mathrm{t}$ & $\mathrm{p}$ \\
\hline \multirow{2}{*}{ Active participation } & Girl & 125 & 2.67 & .27 & \multirow{2}{*}{198} & \multirow{2}{*}{-1.48} & \multirow{2}{*}{.13} \\
\hline & Boy & 75 & 2.73 & .25 & & & \\
\hline \multirow{2}{*}{ Verbal participation } & Girl & 125 & 2.68 & .27 & \multirow{2}{*}{198} & \multirow{2}{*}{.31} & \multirow{2}{*}{.75} \\
\hline & Boy & 75 & 2.67 & .26 & & & \\
\hline \multirow{2}{*}{ Written participation } & Girl & 125 & 2.36 & .28 & \multirow{2}{*}{198} & \multirow{2}{*}{-1.07} & \multirow{2}{*}{.28} \\
\hline & Boy & 75 & 2.41 & .29 & & & \\
\hline \multirow{2}{*}{ Reading participation } & Girl & 125 & 2.47 & .45 & \multirow{2}{*}{198} & \multirow{2}{*}{1.48} & \multirow{2}{*}{.13} \\
\hline & Boy & 75 & 2.38 & .29 & & & \\
\hline \multirow{2}{*}{ Subject inclusion } & Girl & 125 & 2.44 & .38 & \multirow{2}{*}{198} & \multirow{2}{*}{1.29} & \multirow{2}{*}{.19} \\
\hline & Boy & 75 & 2.37 & .35 & & & \\
\hline \multirow{2}{*}{ Measurement and evaluation } & Girl & 125 & 2.28 & .36 & \multirow{2}{*}{198} & \multirow{2}{*}{-2.44} & \multirow{2}{*}{.01} \\
\hline & Boy & 75 & 2.41 & .28 & & & \\
\hline \multirow{2}{*}{ Expectations from the teacher } & Girl & 125 & 2.48 & .14 & \multirow{2}{*}{198} & \multirow{2}{*}{-.29} & \multirow{2}{*}{.77} \\
\hline & Boy & 75 & 2.48 & .11 & & & \\
\hline
\end{tabular}

The results shown in Table 7 have revealed that the students' expectations of their teachers in relation to measurement and evaluation $\left[\mathrm{t}_{(198)}=-2.44\right]$ vary significantly depending on gender $(\mathrm{p}<0.05)$. This difference is in favor of the boys $(X=2.41)$. Thus, it can be argued that the boys attach greater importance to measurement and evaluation than the girls.

\section{CONCLUSION}

As a result of the study, the following conclusions related to the elementary school third year students' expectations of their teachers within the context of the course of language education and their relationship with gender are given below.

The percentage of students' expectation for active participation in the activities conducted within the context of the course of language education was found to be $71.37 \%$. This shows that the students have a high level of expectations. The percentage of the students' expectation for verbal participation in the lesson was found to be $76.75 \%$. Thus, it can be said that most of the students expect the incorporation of activities that will promote their verbal participation. The percentage of the students' expectation for written participation in the course of language education is $53.64 \%$. Thus, more than half of the students always want activities to be done in the course of language education to allow more written participation. The percentage of the students' expectation for participation in reading was found to be $55.92 \%$. As the students' participation in reading in the course of language education is at a good level, the students participate in reading activities to a great extent. The percentage of the students' expectation for the inclusion of the subjects in the course of language education is $56.37 \%$. The students expect their students to allocate more time on subjects related to the course of language education. The percentage of the students' expectation for measurement and evaluation was found to be $52.6 \%$. The students' expectation for measurement and evaluation in the course of language education is high and they are willing to be continuously evaluated. No significant difference based on gender was found for the sub-dimensions of active participation, verbal participation, written participation, reading participation and inclusion of subjects. However, a significant difference based on gender was found for the sub-dimension of measurement and evaluation and this difference is in favour of the boys.

\section{REFERENCES}

[1] K. Açıkgöz, “Aktif öğrenme,” İzmir: Eğitim Dünyas1 Yayınları, 2003.

[2] A. Karaçalı, "Keerem Altun ile öğretmen yeterlikleri üzerine," Bilim ve Aklın Aydınlı̆̆ında Ĕgitim Dergisi, vol.5, 58, pp. 20-26, 2004.

[3] S. Büyükkaragöz and C. Çivi, "Genel öğretim metotlarl” Konya: Öz Eğitim Basım Yayın Dağıtım, 1998.

[4] İ. Fındıkçı, "Yine öğretmenler yeni öğretmenler," Yaşadıkça Ĕgitim Dergisi, vol. 27, 1997.

[5] R.Özkan, "Birey ve toplum gelişiminde öğretmenlik mesleğinin önemi," Milli Eğitim Dergisi, [Online]: http://dhgm.meb.gov.tr/yayimlar/dergiler/milli_egitim_dergisi/166/index3-ozkan.htm, 2005.

[6] S. Sidekli, "İlköğretim dördüncü ve beşinci sınıf öğrencilerinin Türkçe dersi için öğretmenlerinden beklentileri," Milli Eğitim Dergisi, vol.187, pp.52-75, 2010.

[7] M. Tatar, “Öğretmen beklentileri,” Yüzüncü Yll Üniversitesi Eğitim Fakültesi Dergisi, vol.2, http://efdergi.yyu.edu.tr/makaleler/cilt_II/ozetler/m_tatar.htm, 2005.

[8] J.E. Brophy, “Íntroduction”. İn J. Brophy (Ed.), Advences in Research on Teaching: Expectation in the Classroom. Vol 7, London: Ja1 Press Inc., 1998.

[9] R.I. Arends, N.E. Winitzky and M.D. Tannenbaum, “Exploring Teaching,” Boston: The McGraw-Hill, 1998. 
[10] I. Tsiplakides and A. Keramida, "The relationship between teacher expectations and student achievement in the teaching of English as a foreign language," English Language Teaching, 3(2), 22-26, 2010.

[11] J. Chang, "A case study of the "Pygmalion Effect": Teacher Expectations and student achievement," International Education Studies, 4 (1), 198-201, 2011.

[12] M.M. Fall, "Eighth-grade english language learner (ELL) students' perceptions of teacher expectations in relation to classroom motivation," Doctoral dissertation, Capella University, 2017.

[13] S. Strand, "Insights: What accounts for ethnic achievement gap in secondary schools in England" issue 4. Autumn: Retrieved from http://www.education.ox.ac. , 2013.

[14] C. M. Rubie-Davies, "Becoming a high expectation teacher: Raising the bar." London, UK: Routledge, 2015.

[15] E.R. Peterson, C. Rubie-Davies, D. Osborne and C.Sibley, "Teachers' explicit expectations and implicit prejudiced attitudes to educational achievement: Relations with student achievement and the ethnic achievement gap," Learning and Instruction, 42, 123-140, 2016.

[16] C. M. Rubie-Davies, "Teacher expectations and perceptions of student attributes: Is there a relationship ?," British Journal of Educational Pyschology, 80, 121-135, 2010.

[17] Y. Gökbulut, S. Yangın and S.Sidekli, "2004 ilköğretim matematik öğretimi programı doğrultusunda ilköğretim 4. ve 5. sınıf öğrencilerinin öğretmenlerinden matematik dersi için beklentileri," Milli Eğitim Dergisi, vol.179, pp.213-229, 2008.

[18] N. Garner and I. Eilks, "The expections of teachers and student who visit a non-formal student chemistry laboratory," Eurasia Journal of Mathematics, Science \& Technology Education, 11(5), 1197-1210, 2015.

[19] J.H. McMillan and S. Schmacher, "Research in education evidence-based inquiry," 6th Edition, Boston: Allyn and Bacon Inc., 2006.

[20] Ö. Ayva, "Sosyal bilgiler dersi öğrenme öğretme süreci ile ilgili öğrenci görüşleri," International Conference on New Trends in Education and Their Implications, 2010, pp. 276-282.

\section{BIOGRAPHIES OF AUTHORS}

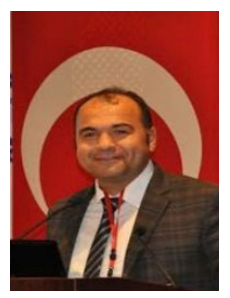

Assoc. Prof. Dr. Sabri SIDEKLİ completed his BA Degree at Atatürk University, Kazım Karabekir Faculty of Education, Primary Education Program and completed his MA and $\mathrm{PhD}$ Degrees at Gazi University, Primary Education Program. He has been working at Muğla Sitk1 Koçman University, Faculty of Education, Elementary Education Department, Primary Education Program. His research interests are primary teacher training, reading and writing disability, skills education, new approaches in teaching and learning, and assessment and evaluation.

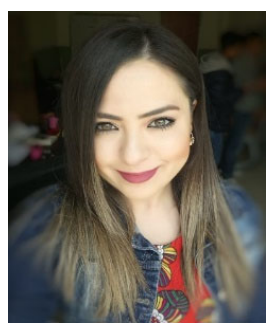

Teacher Zeliha CURA graduated from Giresun University, Primary Education Department. She has been doing her MA at Muğla Sitk1 Koçman University, Primary Education Program. She has also been working as a teacher for Ministry of National Education.

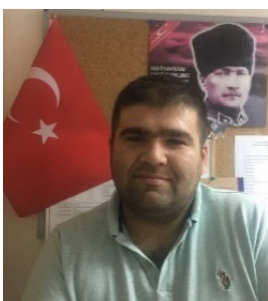

Researcher Alper YORULMAZ has been doing his $\mathrm{PhD}$ at Marmara University, Primary Education Program. He has been working at Muğla S1tk1 Koçman University, Faculty of Education, Elementary Education Department, Primary Education Program. His research interests are Mathematics Education for primary level students, primary teacher training, learning and teaching skills. 